\title{
A Serine-Substituted P450 Catalyzes Highly Efficient Carbene Transfer to Olefins In Vivo
}

\author{
Pedro S. Coelho ${ }^{1}$, Z. Jane Wang ${ }^{1}$, Maraia E. Ener ${ }^{1}$, Stefanie A. Baril ${ }^{2}$, Arvind A. Kannan ${ }^{1}$, \\ Frances H. Arnold ${ }^{1,}$, and Eric M. Brustad ${ }^{2, *}$ \\ ${ }^{1}$ Division of Chemistry and Chemical Engineering, California Institute of Technology, Pasadena, \\ CA 91125, USA \\ 2Department of Chemistry and Carolina Center for Genome Sciences, University of North \\ Carolina at Chapel Hill, Chapel Hill, NC 27599, USA
}

\begin{abstract}
Genetically encoded catalysts for non-natural chemical reactions will open new routes to sustainable production of chemicals. We designed a unique serine-heme ligated cytochrome "P411" that catalyzes efficient and selective carbene transfers from diazoesters to olefins in intact Escherichia coli cells. The mutation $\mathrm{C} 400 \mathrm{~S}$ in cytochrome $\mathrm{P} 450_{\mathrm{BM}}$ gives a signature ferrous-CO Soret peak at $411 \mathrm{~nm}$, abolishes monooxygenation activity, raises the resting state $\mathrm{Fe}^{\mathrm{III} / \mathrm{II}}$ reduction potential, and significantly improves $\mathrm{NAD}(\mathrm{P}) \mathrm{H}$-driven cyclopropanation activity.
\end{abstract}

Genetically programmed whole-cell biocatalysts are readily produced in simple growth media, do not require further purification or isolation and can be engineered with biosynthetic pathways for the elaboration of complex molecules ${ }^{1-3}$. The range of accessible transformations, however, is currently limited to the chemical repertoire of natural enzymes. Designing enzymes for non-natural reactions in vivo has been challenging due to the requirements for assembly of the functional catalyst, the compatibility of synthetic reagents in the cellular milieu, and cell permeability to allow substrate influx and product release. The catalysis of non-natural transformations inside cells will enable alternative biosynthetic routes to natural and artificial products, biocatalytic production of chemicals currently made

\footnotetext{
Users may view, print, copy, download and text and data- mine the content in such documents, for the purposes of academic research, subject always to the full Conditions of use: http://www.nature.com/authors/editorial_policies/license.html\#terms

*Correspondence to: frances@cheme.caltech.edu, brustad@email.unc.edu.

Competing financial interests: PSC, EMB, ZJW and FHA have filed through Caltech a provisional patent application that is based on results presented here.

Author Contributions

PSC, FHA and EMB conceived the project; PSC, EMB and ZJW designed the experiments; EMB and SB performed the crystallization experiments and solved the X-ray structures; MEE performed the redox titrations; PSC, ZJW and AAK performed the catalysis experiments; all authors discussed the results; PSC, EMB and FHA wrote the paper.

Supplementary Information:

Supplementary methods

Supplementary text

Supplementary Figures 1-17

Supplementary Tables 1-12
}

Accession codes: Atomic coordinates and structure factors have been deposited with the PDB (accession codes: 4H23 and 4H24) 
using synthetic reactions, and will expand the chemical toolbox available for in vivo studies of cellular function ${ }^{4}$.

We recently showed that a few amino acid mutations in a bacterial cytochrome P450 monooxygenase can unlock significant cyclopropanation activity in vitro. Variants of $\mathrm{P}^{4} 50_{\mathrm{BM} 3}$ from Bacillus megaterium catalyze hundreds of turnovers of formal carbene transfers from diazoesters (e.g. ethyl diazoacetate, EDA) to olefins (e.g. styrene) in the presence of a reductant, forming cyclopropane products with high levels of diastereo- and enantioselectivity ${ }^{5}$. Olefin cyclopropanation is widely used in the synthesis of fine chemicals ${ }^{6}$, and state-of-the-art asymmetric organometallic catalysts are able to catalyze thousands to tens of thousands of turnovers ${ }^{7-9}$. Because $\mathrm{P} 450_{\mathrm{BM} 3}$ variants are readily expressed in functional form and can catalyze non-natural carbene transfers without requiring artificial cofactors or posttranslational modifications, we hypothesized that this system may be suitable for in vivo catalysis. To initiate the catalytic cycle inside a cell, it is necessary to reduce the enzyme to the catalytically active ferrous-P450 with an endogenous reducing agent such as $\mathrm{NAD}(\mathrm{P}) \mathrm{H}$. Based on consideration of heme ligation control of the $\mathrm{P} 450 \mathrm{Fe}^{\mathrm{III}} / \mathrm{Fe}^{\mathrm{II}}$ reduction potential, we have designed genetically encoded cytochrome $\mathrm{P} 411$ enzymes which catalyze efficient and selective olefin cyclopropanation in intact cells.

Cytochrome $\mathrm{P} 450_{\mathrm{BM} 3}$-catalyzed cyclopropanations require substoichiometric (with respect to diazoester and olefin) reductant and proceed optimally under anaerobic conditions ${ }^{5}$. This suggests that diazoester activation and carbene transfer involve a reduced $\mathrm{P} 450$-bound $\mathrm{Fe}^{\mathrm{II}}$ heme prosthetic group as opposed to the resting state $\mathrm{Fe}^{\mathrm{III}}$-heme (Fig. 1A). Active cyclopropanation catalysts derived from either full-length $\mathrm{P} 450_{\mathrm{BM} 3}$, which contains a catalytic heme domain fused to a NADPH-driven P450-reductase domain, or the isolated heme domain ( $\left.\mathrm{P} 450_{\mathrm{BM} 3-h e m e}\right)$ show marked preference for strong reducing agents such as dithionite $\left(E^{\circ \prime}=-660 \mathrm{mV}\right.$, all potentials vs SHE) over native $\mathrm{NAD}(\mathrm{P}) \mathrm{H}\left(E^{\circ \prime}=-320 \mathrm{mV}\right)^{5}$. Reduced activity in the presence of $\mathrm{NAD}(\mathrm{P}) \mathrm{H}$ suggests a limited substrate-induced low-spin $\left(E^{\circ} / \mathrm{Fe}^{\mathrm{III} / \mathrm{II}}=-430 \mathrm{mV}\right)$ to high-spin $\left(E^{\circ} / \mathrm{Fe}^{\mathrm{III} / \mathrm{II}}=-290 \mathrm{mV}\right)$ transition of the $\mathrm{P} 450$ hemeiron ${ }^{10}$, which, while essential for monooxygenation, may not be achievable in this engineered system due to the poor affinity for the non-natural substrates (where weak substrate binding is suggested by a $K_{M}$ value of $\left.\sim 5 \mathrm{mM}\right)^{5}$. We hypothesized that raising the reduction potential of the resting state enzyme to facilitate $\mathrm{NAD}(\mathrm{P}) \mathrm{H}$-driven reduction would enhance $\mathrm{Fe}^{\mathrm{II}}$ catalysis in vivo. Aware that the reduction potential of heme proteins can be tuned by axial ligand mutations ${ }^{11,12}$, we reasoned that substituting the axial cysteine thiolate in $\mathrm{P} 450_{\mathrm{BM}}$ with the weakly donating serine alcohol should raise the $\mathrm{Fe}$ potential [Fig. 1A]. Furthermore, axial cysteinate ligation is essential for dioxygen activation and stabilization of the active ferryl-porphyrin cation radical oxidant (compound I) during monooxygenation ${ }^{13}$, and axial cysteine to serine substitutions have been reported to abolish monooxygenation activity in mammalian P450s ${ }^{14}$. Because free hemin is also a (poor) cyclopropanation catalyst ${ }^{5}$, we anticipated that an axial cysteine to serine mutation (C400S in $\mathrm{P}^{4} 0_{\mathrm{BM} 3}$ ) would maintain carbene transfer activity while eliminating monooxygenation activity.

We chose to introduce the $\mathrm{C} 400 \mathrm{~S}$ mutation into a cis-selective cyclopropanation catalyst from our previous work, $\mathrm{P} 450_{\mathrm{BM}}{ }^{-} \mathrm{CIS}$ [13 mutations from $\mathrm{P} 450_{\mathrm{BM} 3}$, Online Methods], to 
contrast with the trans-selectivity observed with iron-porphyrins ${ }^{15}$. $\mathrm{P} 450_{\mathrm{BM} 3}$-CIS catalyzes hundreds of turnovers in the presence of dithionite in vitro and forms the ethyl 2phenylcyclopropane-1-carboxylate product with $71 \%$ cis-selectivity and $94 \%$ enantiomeric excess $\left(e e_{c i s}\right)^{5}$. UV-vis spectra for the green-brown P450 BM3 $_{3}$-CIS-C400S (P411 $1_{\mathrm{BM} 3}$-CIS, Supplementary Results, Supplementary Figs. 1-3), marked by a ferrous carbon monoxidebound complex at $411 \mathrm{~nm}$, were consistent with those reported for a Ser-ligated mammalian $\mathrm{P} 450^{14,16}$ (Supplementary Table 1). Because of this signature Fe ${ }^{\mathrm{II}}-\mathrm{CO}$ band at $411 \mathrm{~nm}$, we call these new P450-derived Ser-ligated enzymes cytochrome "P411s", and will refer to the C400S P450 ${ }_{\mathrm{BM} 3}$ variants as "P411 ${ }_{\mathrm{BM} 3}$ " enzymes. Heme-serine ligation in $\mathrm{P}_{111_{\mathrm{BM} 3}-\mathrm{CIS}}$ was further confirmed by determining the crystal structures of the $\mathrm{P}^{450} \mathrm{BM}_{\mathrm{BM}}-\mathrm{CIS}$ and

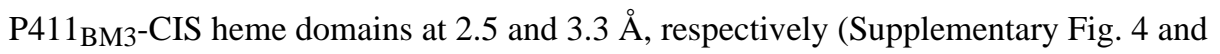
Supplementary Table 2, PDB: 4H23 and 4H24); the structures were superimposable (RMSD $=0.52 \AA$, Supplementary Fig. 4). Despite the limited resolution of the P411 $1_{\mathrm{BM} 3}$-CIS structure, simulated annealing omit maps generated in the absence of modeled heme and C400S showed density consistent with heme coordination by a proximal amino acid side chain (Fig. 1B and Supplementary Fig. 5).

Potentiometric redox titrations were performed using the truncated heme domains of wildtype $\mathrm{P} 450_{\mathrm{BM} 3}$, its $\mathrm{C} 400 \mathrm{~S}$ variant $\left(\mathrm{P} 411_{\mathrm{BM} 3}\right), \mathrm{P} 450_{\mathrm{BM} 3}-\mathrm{CIS}$ and $\mathrm{P} 411_{\mathrm{BM} 3}-\mathrm{CIS}$ (Supplementary Figs. 6 to 9). The C400S mutation raised the reduction potential of the resting state wild-type $\mathrm{P} 450_{\mathrm{BM} 3}$-heme by $+127 \mathrm{mV}\left(E^{\circ /} \mathrm{Fe}^{\mathrm{III} / \mathrm{II}}\right.$ Ser $=-293 \mathrm{mV}$ for P411 $1_{\mathrm{BM} 3-h e m e}$ ), a shift similar in magnitude to that which occurs in $\mathrm{P} 450_{\mathrm{BM}}$ upon substrate binding ${ }^{10}$. The 13 amino acid mutations in $\mathrm{P} 450_{\mathrm{BM} 3-\text { heme }}$-CIS increased the reduction potential by $+60 \mathrm{mV}$ with respect to wild-type $\mathrm{P} 450_{\mathrm{BM} 3-\text { heme }}\left(E^{\circ /} \mathrm{Fe}^{\mathrm{III} / \mathrm{II}} \mathrm{Cys}=-360 \mathrm{mV}\right.$ for P450 ${ }_{\mathrm{BM} 3-h e m e}$-CIS), but still left $\mathrm{P} 450_{\mathrm{BM} 3-\text { heme }^{-C}}$-CIS with a lower reduction potential than $\mathrm{NAD}(\mathrm{P})^{+} / \mathrm{NAD}(\mathrm{P}) \mathrm{H}$. Introducing the $\mathrm{C} 400 \mathrm{~S}$ mutation in $\mathrm{P} 450_{\mathrm{BM} 3-\text { heme}}-\mathrm{CIS}$ raised its reduction potential by another $+95 \mathrm{mV}\left(E^{\circ /} \mathrm{Fe}^{\mathrm{III} / \mathrm{II}}\right.$ Ser $=-265 \mathrm{mV}$ for $\mathrm{P} 411_{\mathrm{BM}}$-heme-CIS $)$. That the two C400S enzymes have resting state reduction potentials more positive than that of $\mathrm{NAD}(\mathrm{P})^{+} / \mathrm{NAD}(\mathrm{P}) \mathrm{H}$ should allow full-length $\mathrm{P} 411$ s to be reduced by $\mathrm{NAD}(\mathrm{P}) \mathrm{H}$ even in the absence of substrate.

The truncated $\mathrm{P} 411_{\mathrm{BM} 3-\text { heme}}$-CIS was an active dithionite-driven cyclopropanation catalyst in vitro, with Michaelis-Menten parameters $\left(k_{\text {cat }}=82 \mathrm{~min}^{-1}, K_{M \text {-styrene }}=4.6 \mathrm{mM}, K_{M-E D A}\right.$ $=5.7 \mathrm{mM}$, Supplementary Fig. 10), comparable to those of P450 $\mathrm{BM} 3$-heme ${ }^{-\mathrm{CIS}}$

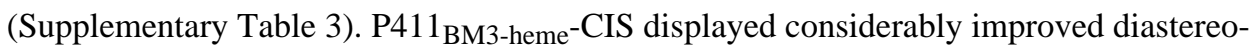
(cis:trans 93:7) and enantioselectivity $\left(99 \% \mathrm{ee}_{\text {cis }}\right.$ ) compared to its cysteine homologue (Supplementary Table 4 and Supplementary Fig. 11), an unexpected result given the similar active site geometries of the two catalysts (Supplementary Fig. 4). For a variety of styrenyl substrates, $\mathrm{P} 411_{\mathrm{BM} 3-\text { heme}}$-CIS showed superior cis-selectivity relative to $\mathrm{P} 450_{\mathrm{BM} 3-\text { heme-CIS }}$ (Supplementary Table 5). The full-length, reductase-fused P411 BM3 $_{3}$-CIS showed increased activity compared to holo $\mathrm{P}^{4} 0_{\mathrm{BM} 3}$-CIS when NADPH was used as the reductant under anaerobic conditions (Fig. 1C and Supplementary Table 6). P450 BM3 $_{3}$-CIS only formed small amounts of cyclopropanes when NADPH was used, and formed styrene oxide, via monooxygenation, as the major product under aerobic conditions. In contrast, $\mathrm{P} 41_{\mathrm{BM}}{ }$-CIS produced negligible amounts of styrene oxide, confirming removal of monooxygenase 
activity, and was still able to form cyclopropanes under aerobic conditions, albeit with lower yields (43 TTN) due to oxygen inhibition (Fig. 1C). Dioxygen inhibition could be due to a two-electron oxidase activity as reported for CYP2B4-C436S ${ }^{14}$. NADH drove P411 BM3- $^{-}$ CIS-mediated cyclopropanation as efficiently as NADPH (Supplementary Table 7), suggesting that $\mathrm{P} 411_{\mathrm{BM} 3}$-CIS should be well suited for in vivo catalysis under anaerobic conditions where NADPH biosynthesis in E. coli does not take place. The apparent lack of the substoichiometric cofactor preference for cyclopropanation TTN contrasts with $\mathrm{P}_{450}{ }_{\mathrm{BM} 3}$ 's reported specificity for $\mathrm{NADPH}^{17}$.

We next investigated the efficiency of cyclopropanation using resting Escherichia coli [BL21(DE3)] cells grown in M9Y media [M9, 1.5\% yeast extract, Online Methods] expressing full-length $\mathrm{P} 450_{\mathrm{BM} 3}-\mathrm{CIS}$ and $\mathrm{P} 411_{\mathrm{BM}_{3}}-\mathrm{CIS}$. Addition of glucose under anaerobic conditions significantly increased product yield (Supplementary Table 8), presumably due to enhanced intracellular production of NADH, although other cellular reductants could also be involved in reducing the enzyme in vivo. $\mathrm{P} 411_{\mathrm{BM}}$-CIS catalyzed thousands of turnovers in vivo, was about four times more active than $\mathrm{P}^{4} 0_{\mathrm{BM}} \mathrm{B}^{-\mathrm{CIS}}$ in the whole-cell system, and provided cyclopropane products with enhanced cisenantioselectivity (Table 1, entries 1 and 2). The C400S mutation compromises protein expression such that $\mathrm{P} 411_{\mathrm{BM} 3}$-CIS accounts for $2 \%$ of dry cell mass compared to $6 \%$ for $\mathrm{P}_{450} \mathrm{BM}_{3}$-CIS (entries 1 and 2). The reduced expression was not due to decreased protein stability, as C400S contributed to increased thermostability in the purified P411 $1_{\mathrm{BM}} 3^{-\mathrm{CIS}}$

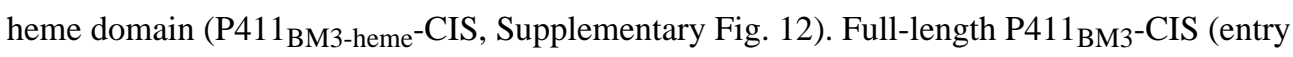
2 ), which contains both heme and diflavin reductase domains, was over two times more active on a molar basis than the truncated heme domain (P411 BM3-heme-CIS, entry 3), confirming that reduction to the ferrous state in vivo was important, but also showing that the reducing intracellular environment achieved heme reduction even in the absence of the

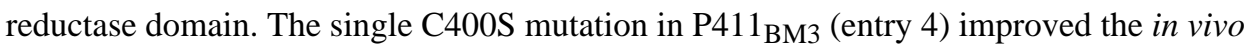
cyclopropanation activity of wild-type $\mathrm{P} 450_{\mathrm{BM} 3}$ (entry 5) by over two orders of magnitude. Purified full-length $\mathrm{P} 411_{\mathrm{BM} 3}$ was also an efficient NADH-driven cyclopropanation catalyst in vitro, whereas $\mathrm{P} 450_{\mathrm{BM} 3}$ was barely active (Supplementary Table 9).

Both P411 BM3 -CIS and P450 ${ }_{\mathrm{BM}_{3}}$-CIS whole cells were significantly inhibited by dioxygen (Supplementary Fig. 13). Whole cells containing the P411 BM3 $_{3}$-CIS gene but with no induction and whole cells devoid of the $\mathrm{P} 411_{\mathrm{BM} 3}$-CIS gene were able to form small amounts of cyclopropanes, but did so with stereoselectivity similar to that of free hemin (Supplementary Table 10 and Fig. 14). This is not surprising since free hemin and other heme proteins present in cells are also able to catalyze styrene cyclopropanation at low levels ${ }^{5}$. Whole-cell $\mathrm{P} 411_{\mathrm{BM} 3}$-CIS catalysts were as stereoselective as purified $\mathrm{P} 411_{\mathrm{BM} 3}$-CIS in vitro at equivalent catalyst loading (vide infra), demonstrating that the overexpressed P411 enzyme outcompeted background catalysis. In vivo cyclopropanation was strongly inhibited by carbon monoxide (Table 1, entry 6), which irreversibly binds ferrous heme in vitro; as the bacteria are tested in stationary phase and $\mathrm{CO}$ is thus unlikely to cause overall cell death via poisoning of the respiratory chain, this result provides support for catalysis occurring in the enzyme active site. Yield could be increased to $80 \%$ by increasing the cell density up to $\mathrm{OD}_{600}=50$ (Supplementary Fig. 15). Using excess styrene only slightly 
improved reaction yield (Supplementary Fig. 16). Lysate of cells expressing full-length P411 BM3 -CIS that were supplemented with NADH retained only about $30 \%$ of the activity of the intact whole cells and were not active in the absence of exogenous reductant (Supplementary Table 11). Addition of dithionite inhibited P411 BM3 $_{3}$-CIS whole-cell reactions and was less efficient than NADH in driving the reaction in cell lysate (Supplementary Tables 10 and 11).

In order to provide a direct comparison of full-length $\mathrm{P} 411_{\mathrm{BM}}{ }$-CIS activity in vivo versus in vitro, we monitored both reactions at the same enzyme concentration over 8 hours (Supplementary Fig. 17). On a molar basis, the in vivo catalyst showed almost 6 times higher TTN than the purified enzyme after 6 hours and retained the same stereoselectivity (75:25 cis:trans, $\left.95 \% e e_{c i s}\right)$. Both catalysts remained active over this period, suggesting that the observed differences in yield and TTN are due to improved activity rather than enhanced catalyst stability in vivo. Gradual addition of EDA did not improve the reaction yield.

At high substrate loading (170 mM EDA, $400 \mathrm{mM}$ styrene, added as neat reagents), more than 60,000 catalytic turnovers were observed in the in vivo reaction with $\mathrm{P}_{411_{\mathrm{BM} 3} \text {-CIS }}$ (Table 1, entry 7). P411 BM3$_{3}$-CIS whole-cell reactions were readily scalable to make gram quantities of cyclopropanes with high stereoselectivity, product titer $\left(27 \mathrm{~g} \mathrm{~L}^{-1}\right)$ and yield (78\%, entry 8). No organic cosolvent was necessary, and the cyclopropane products were readily obtained by extraction with organic solvent at the end of the reaction (Online

Methods). Furthermore, the cells could be lyophilized with a cryoprotectant such as sucrose and stored as a powder for weeks at $4{ }^{\circ} \mathrm{C}$ without degradation of catalytic activity or diastereo- and enantioselectivity (Supplementary Table 12). Lyophilized cells can be readily packaged and distributed. These features render whole-cell P411 catalysts attractive for facile benchtop synthesis.

Cytochrome P411s are spectroscopically, electrochemically, and catalytically distinct from cytochrome P450s, providing a scaffold for engineering orthogonal heme-enzyme catalysis. Whole-cell catalysts based on serine-heme ligated P411s are easy to use and deliver enzymatic cyclopropanation with high conversion, optical purity and yield for substrate input in the tens of grams per liter. The ability to catalyze this non-natural C-C bond forming reaction in vivo will expand the scope of transformations accessible to microbial organic synthesis and should provide artificial metabolic pathways to complement nature's existing strategies for making cyclopropanes ${ }^{18}$.

\section{Online Methods}

\section{Materials and methods}

All reagents were obtained from commercial suppliers (Sigma-Aldrich) and used without further purification. ${ }^{1} \mathrm{H}$ and ${ }^{13} \mathrm{C}$ NMR spectra were recorded on either a Varian Mercury 300 spectrometer (300 MHz and $75 \mathrm{MHz}$, respectively), or a Varian Inova $500 \mathrm{MHz}(500 \mathrm{MHz}$ and $125 \mathrm{MHz}$, respectively), and are internally referenced to residual solvent peak. Highresolution mass spectra were obtained with a JEOL JMS-600H High Resolution Mass Spectrometer. Gas chromatography (GC) analyses were carried out using a GC-17A gas chromatograph (Shimadzu), a FID detector, and a J\&W cyclosil-B column $(30 \mathrm{~m} \times 0.25$ 
$\mathrm{mm}, 0.25 \mu \mathrm{m}$ film, Agilent) and 2-phenylethanol as an internal standard. Injector temperature $=300{ }^{\circ} \mathrm{C}$, oven temperature $=130{ }^{\circ} \mathrm{C}$ for $30 \mathrm{~min}$, pressure $=175 \mathrm{kPa}$. Elution time: cis-cyclopropanes [19.7 $\mathrm{min}(2 R, 1 S)$ and $21.0 \mathrm{~min}(2 S, 1 R)]$, trans-cyclopropanes [25.8 $\min (2 R, 1 R)$ and $26.4 \min (2 S, 1 S)]$. Cyclopropane product standards for the reaction of ethyl diazoacetate (EDA) with styrene (ethyl 2-phenylcyclopropane-1-carboxylate) and amethylstyrene (ethyl 2-methyl-2-phenylcyclopropane-1-carboxylate) were prepared as reported ${ }^{19}$. These standards and enzyme-prepared cyclopropanes demonstrated identical retention times in gas chromatograms when co-injected, confirming product identity. Absolute stereoconfiguration of cyclopropane enantiomers was determined by measuring optical rotation of purified cyclopropane products from preparative bioconversion reactions using enantioselective $\mathrm{P} 450_{\mathrm{BM} 3}$ variants and referenced to values taken from reference ${ }^{20}$. Authentic $\mathrm{P} 450$-catalyzed cyclopropane samples were also prepared and were characterized by NMR $\left({ }^{1} \mathrm{H}\right.$ and $\left.{ }^{13} \mathrm{C}\right)$ and mass spectrometry, which matched literature values.

Plasmids pCWori $\left[\mathrm{P} 40_{\mathrm{BM} 3}\right]$ and $\mathrm{pET} 22$ were used as cloning vectors. The $\mathrm{C} 400 \mathrm{~S}$ mutation was introduced by standard overlap mutagenesis using primers bearing the desired mutation (IDT, San Diego, CA).

Forward Primers:

\section{HF1: CAGGAAACAGGATCAGCTTACTCCCC}

BM3_C400S_F_nheI: GAAACGGTCAGCGTGCTAGCATCGGTCAGCAGTTCG

Respective Reverse Primers:

\section{BM3_C400S_R_nheI: CGAACTGCTGACCGATGCTAGCACGCTGACCGTTTC}

pCWori-Rev: GCGTATCACGAGGCCCTTTCGTCTTCAAGC

Electrocompetent Escherichia coli cells were prepared following the protocol of Sambrook et al. ${ }^{21}$. Restriction enzymes BamHI, EcoRI, XhoI, Phusion polymerase, and T4 ligase were purchased from New England Biolabs (NEB, Ipswich, MA). Alkaline phosphatase was obtained from Roche (Nutley, NJ). The 1,000x trace metal mix used in expression cultures contained $50 \mathrm{mM} \mathrm{FeCl}_{3}, 20 \mathrm{mM} \mathrm{CaCl}_{2}, 10 \mathrm{mM} \mathrm{MnSO}_{4}, 10 \mathrm{mM} \mathrm{ZnSO}_{4}, 2 \mathrm{mM} \mathrm{CoSO}_{4}, 2$ $\mathrm{mM} \mathrm{CuCl}_{2}, 2 \mathrm{mM} \mathrm{NiCl}_{2}, 2 \mathrm{mM} \mathrm{Na}_{2} \mathrm{MoO}_{4}$, and $2 \mathrm{mM} \mathrm{H}_{3} \mathrm{BO}_{3}$.

\section{CO binding assay}

$\mathrm{P} 450$ concentration was determined from ferrous $\mathrm{CO}$ binding difference spectra using extinction coefficients of $\varepsilon_{450-490}=91 \mathrm{mM}^{-1} \mathrm{~cm}^{-1}$ for cysteine-ligated $\mathrm{P} 450_{\mathrm{BM} 322}$ and $\varepsilon_{411-490}=103 \mathrm{mM}^{-1} \mathrm{~cm}^{-1}$ for serine ligated $\mathrm{P} 411_{\mathrm{BM} 314}$. The in vivo $\mathrm{P} 450$ (or $\mathrm{P} 411$ ) concentration was determined by conducting the $\mathrm{CO}$ assay in the lysate of an aliquot of cells in the same cell density as used for the whole-cell reactions.

\section{P450 expression and purification}

For in vitro cyclopropanation reactions, $\mathrm{P} 450_{\mathrm{BM} 3}$ variants were used in purified form. Enzyme batches were prepared as follows. One liter $\mathrm{TB}_{\mathrm{amp}}$ was inoculated with an overnight culture ( $100 \mathrm{~mL}, \mathrm{LB}_{\mathrm{amp}}$ ) of recombinant $E$. coli BL21(DE3) cells harboring a pCWori plasmid encoding the $\mathrm{P} 450$ variant under the control of the tac promoter. After 3.5 
$\mathrm{h}$ of incubation at $37^{\circ} \mathrm{C}$ and $250 \mathrm{rpm}$ shaking $\left(\mathrm{OD}_{600} \mathrm{ca} .1 .8\right)$, the incubation temperature was reduced to $25^{\circ} \mathrm{C}$ ( $30 \mathrm{~min}$ ), and the cultures were induced by adding IPTG to a final concentration of $0.5 \mathrm{mM}$. The cultures were allowed to continue for another 24 hours at this temperature. After harvesting the cells by centrifugation $\left(4^{\circ} \mathrm{C}, 15 \mathrm{~min}, 3,000 \times \mathrm{g}\right)$, the cell pellet was stored at $-20^{\circ} \mathrm{C}$ until further use but at least for $2 \mathrm{~h}$. The cell pellet was resuspended in $25 \mathrm{mM}$ Tris. $\mathrm{HCl}$ buffer $\left(\mathrm{pH} 7.5\right.$ at $25^{\circ} \mathrm{C}$ ) and cells were lysed by sonication ( $2 \times 1 \mathrm{~min}$, output control 5, 50\% duty cycle; Sonicator, Heat Systems-Ultrasonic, Inc.). Cell debris was removed by centrifugation for $20 \mathrm{~min}$ at $4{ }^{\circ} \mathrm{C}$ and $27,000 \times g$ and the supernatant was subjected to anion exchange chromatography on a Q Sepharose column (HiTrapTM Q HP, GE Healthcare, Piscataway, NJ) using an AKTAxpress purifier FPLC system (GE healthcare). The P450 (or P411) was eluted from the Q column by running a gradient from 0 to $0.5 \mathrm{M} \mathrm{NaCl}$ over 10 column volumes. The $\mathrm{P} 450$ (or $\mathrm{P} 411$ ) fractions were collected and concentrated using a $30 \mathrm{kDa}$ molecular weight cutoff centrifugal filter and buffer-exchanged with $0.1 \mathrm{M}$ phosphate buffer $(\mathrm{pH}=8.0)$. The purified protein was flashfrozen on dry ice and stored at $-20{ }^{\circ} \mathrm{C}$.

For crystallization experiments, a two-step purification was performed using the AKTAxpress purifier FPLC system. Frozen cell pellets containing expressed, 6XHis tagged heme domains were resuspended in Ni-NTA buffer A ( $25 \mathrm{mM}$ Tris. $\mathrm{HCl}, 200 \mathrm{mM} \mathrm{NaCl}, 25$ $\mathrm{mM}$ imidazole, $\mathrm{pH} 8.0,0.5 \mathrm{~mL} / \mathrm{gcw})$ and lysed by sonication $(2 \times 1 \mathrm{~min}$, output control 5 , $50 \%$ duty cycle). The lysate was centrifuged at $27,000 \times g$ for $20 \mathrm{~min}$ at $4{ }^{\circ} \mathrm{C}$ to remove cell debris. The collected supernatant was first subjected to a Ni-NTA chromatography step using a Ni sepharose column (HisTrap-HP, GE healthcare, Piscataway, NJ). The P450 (or P411) was eluted from the Ni sepharose column using $25 \mathrm{mM}$ Tris. $\mathrm{HCl}, 200 \mathrm{mM} \mathrm{NaCl}, 300$ $\mathrm{mM}$ imidazole, $\mathrm{pH}$ 8.0. Ni-purified protein was buffer exchanged into $25 \mathrm{mM}$ Tris. $\mathrm{HCl} \mathrm{pH}$ 7.5 using a $30 \mathrm{kDa}$ molecular weight cutoff centrifugal filter and subsequently loaded onto a Q sepharose column (HiTrapTM Q HP, GE healthcare, Piscataway, NJ) and purified to homogeneity by anion exchange. The P450 (or P411) was eluted from the Q column by running a gradient from 0 to $0.5 \mathrm{M} \mathrm{NaCl}$ over 10 column volumes. $\mathrm{P} 450$ (or P411) fractions were collected and buffer exchanged into $25 \mathrm{mM}$ Tris. $\mathrm{HCl} \mathrm{pH} \mathrm{7.5,} 25 \mathrm{mM} \mathrm{NaCl}$. The purified protein was concentrated with a $30 \mathrm{kDa}$ molecular weight cut-off centrifugal filter to approximately $10 \mathrm{mg} \mathrm{mL}^{-1}$. Aliquots $(50 \mu \mathrm{L})$ were flash frozen on dry ice and stored at $-80{ }^{\circ} \mathrm{C}$ until needed.

Mutations in cyclopropanation catalysts are reported with respect to wild-type $\mathrm{P} 450_{\mathrm{BM} 3}$. The heme domain comprises the first 462 amino acids in the $\mathrm{P} 450_{\mathrm{BM} 3}$ sequence. $\mathbf{P 4 1 1}_{\mathbf{B M 3}}=$ $\mathrm{P} 450_{\mathrm{BM} 3}+\mathrm{C} 400 \mathrm{~S} . \mathrm{P} 450_{\mathrm{BM} 3}-\mathrm{CIS}=\mathrm{P} 450_{\mathrm{BM} 3}+\mathrm{V} 78 \mathrm{~A}, \mathrm{~F} 87 \mathrm{~V}, \mathrm{P} 142 \mathrm{~S}, \mathrm{~T} 175 \mathrm{I}, \mathrm{A} 184 \mathrm{~V}$, S226R, H236Q, E252G, T268A A290V, L353V, I366V, E442K. P411 BM3 $^{-}$-CIS = P450 BM3- $^{-}$ CIS + C400S.

\section{Protein crystallography}

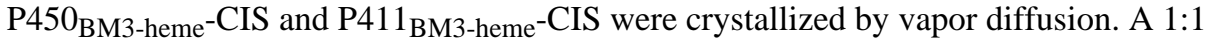

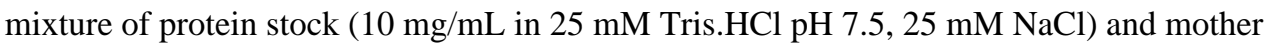
liquor was combined in 24 well sitting drop plates (Hampton Research). Optimal crystallization conditions for $\mathrm{P}_{50} 0_{\mathrm{BM} 3-\text { heme }^{-}} \mathrm{CIS}$ were found in $0.1 \mathrm{M}$ sodium cacadolyte, 


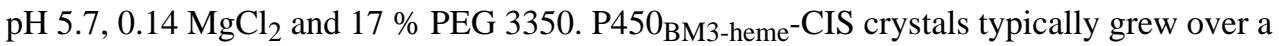
span of 7 - 14 days. P411 1 BM3-heme-CIS crystals optimally formed in $0.1 \mathrm{M}$ Bis-Tris, pH 5.3, $0.2 \mathrm{M}$ sodium formate and 18\% PEG 3350. Initial P411 1 BM3-heme-CIS drops are marked with a dense layer of protein precipitate; however, after $36-48$ hours, noticeable protein crystals were observed underneath the precipitate layer.

\section{X-ray data collection and protein structure determination}

$\mathrm{X}$-ray diffraction data were collected at the General Medical Sciences and Cancer Institutes Structural Biology Facility (GM/CA) at the Advanced Photon Source (APS, Argonne National Laboratory) using beamline ID23-D and a MAR300 CCD detector. Data were collected at $100 \mathrm{~K}$ and a wavelength of $1.033 \AA$ A . Data collections statistics are listed in Supplementary Table 2. Diffraction datasets were integrated with $\mathrm{XDS}^{23}$ and scaled using SCALA $^{24}$. Initial phases were determined by molecular replacement against the closed form of wild type $\mathrm{P} 450_{\mathrm{BM}} 3$-heme structure taken from PDB $1 \mathrm{JPZ}^{25}$, chain B using MOLREP software $^{26}$, a component of the CCP4 crystallography software suite ${ }^{27}$. Refinement was accomplished by iterative cycles of manual model building within $\mathrm{COOT}^{28}$ and automated refinement using REFMAC ${ }^{29}$ within CCP4. Final cycles of REFMAC refinement included TLS parameters. Non-crystallographic symmetry constraints were not used during refinement. Model quality was assessed using the 'complete validation' tool inside of the PHENIX software suite ${ }^{30}$. Simulated annealing omit maps were also calculated using Phenix. Ramachandran outliers generally lie in poorly structured loops connecting $\mathrm{P} 450_{\mathrm{BM} 3-\text { heme }} \mathrm{F}$ and $\mathrm{G}$ helices. These residues are often missing or marked by poor density in these and other $\mathrm{P} 450_{\mathrm{BM} 3 \text {-heme }}$ structures within the protein database. All protein structure figures and alignments were generated using PyMol software (The PyMOL Molecular Graphics System, Version 1.3, Schrödinger, LLC.).

\section{Potentiometric titrations}

Enzyme samples were buffer-exchanged into $100 \mathrm{mM} \mathrm{KPO}_{4}, 100 \mathrm{mM} \mathrm{KCl}, \mathrm{pH} 7.4$, and deoxygenated via $4 \times 20$ gentle pump-backfill cycles with argon, with care taken to avoid bubbling. Potentiometric redox titrations were performed in an anaerobic glove box, using a quartz spectroelectrochemical cell with path length of $1 \mathrm{~mm}$, platinum mesh working electrode, platinum wire counter electrode, and a $\mathrm{Ag} / \mathrm{AgCl}$ electrode (Bioanalytical Systems, Inc.) was used as the reference ( $\mathrm{Ag} / \mathrm{AgCl}$ vs NHE: $+197 \mathrm{mV})$. Protein solutions consisted of approximately $600 \mu \mathrm{L}$ of $50-100 \mu \mathrm{M}$ protein with the following mediators added to ensure electrochemical communication between the protein and electrode: methyl viologen $(5 \mu \mathrm{M})$, benzyl viologen $(10 \mu \mathrm{M})$ and 2-hydroxy-1,4-napthaquinone $(20 \mu \mathrm{M})$. Enzyme samples were titrated using sodium dithionite (reduction) and potassium ferricyanide (re-oxidation). The open circuit potential (OCP) of the cell was monitored (WaveNow potentiostat, Pine Research Instrumentation) over a 10 minute equilibration period, and spectra were recorded using a Ocean Optics spectrometer (USB2000+). The reduction potentials $\left(E^{\circ}\right)$ were determined by fitting the data to the one-electron Nernst equation, $\mathrm{E}^{\prime}(\mathrm{cell})=\mathrm{E}^{0}$ $-0.59 * \log \left(\left[\mathrm{Fe}^{\mathrm{II}}\right] /\left[\mathrm{Fe}^{\mathrm{III}}\right]\right)$, where the only adjustable parameter is $\mathrm{E}^{0 \prime}$. Each point on a titration curve corresponds to the measurement from a single titration; coarse titrations were repeated for the enzymes: $\mathrm{P} 450_{\mathrm{BM} 3}$, and $\mathrm{P} 411_{\mathrm{BM} 3}$-CIS with nearly identical results. Estimated error for each OCP is less than $15 \mathrm{mV}$, based on the average drift in OCP 
measured at 600 points over 10 minutes. For measurements where the drift over 10 minutes exceeded $15 \mathrm{mV}$, the OCP was monitored for an additional $5 \mathrm{~min}$ or until the potential stabilized. Estimated error for each $\% \mathrm{Fe}^{\mathrm{II}}$ is approximately $3 \%$ based on the average variation between $\% \mathrm{Fe}^{\mathrm{II}}$ determined at $2-4$ different wavelengths. All titration points were fit to a single one-electron Nernst curve.

\section{Typical procedure for in vitro small-scale cyclopropanation bioconversions under anaerobic conditions}

Small-scale reactions ( $400 \mu \mathrm{L}$ ) were conducted in $2 \mathrm{~mL}$ crimp vials (Agilent Technologies, San Diego, CA). P450 solution $(80 \mu \mathrm{L}, 100 \mu \mathrm{M})$ was added to the vial with a small stir bar before crimp sealing with a silicone septum. Phosphate buffer $(260 \mu \mathrm{L}, 0.1 \mathrm{M}, \mathrm{pH}=8.0)$ and $40 \mu \mathrm{L}$ of a solution of the reductant ( $100 \mathrm{mM} \mathrm{Na}_{2} \mathrm{~S}_{2} \mathrm{O}_{4}$, or $\left.20 \mathrm{mM} \mathrm{NADPH}\right)$ were combined in a larger crimp-sealed vial and degassed by bubbling argon through the solution for at least 5 min. In the meantime, the headspace of the $2 \mathrm{~mL}$ reaction vial with the $\mathrm{P} 450$ (or P411) solution was made anaerobic by flushing argon over the protein solution (with no bubbling). When multiple reactions were conducted in parallel, up to 8 reaction vials were degassed in series via cannulae. The buffer/reductant solution $(300 \mu \mathrm{L})$ was syringed into the reaction vial, while under argon. The gas lines were disconnected from the reaction vial before placing the vials on a plate stirrer. A $40 \times$ styrene solution in $\mathrm{MeOH}(10 \mu \mathrm{L}$, typically $1.2 \mathrm{M})$ was added to the reaction vial via a glass syringe, and left to stir for about $30 \mathrm{~s}$. A 40× EDA solution in $\mathrm{MeOH}$ was then added ( $10 \mu \mathrm{L}$, typically $400 \mathrm{mM})$ and the reaction was left stirring for the appropriate time. The final concentrations of the reagents were typically: 30 $\mathrm{mM}$ styrene, $10 \mathrm{mM}$ EDA, $10 \mathrm{mM} \mathrm{Na}_{2} \mathrm{~S}_{2} \mathrm{O}_{4}, 20 \mu \mathrm{M} 450$. The reaction was quenched by adding $30 \mu \mathrm{L} \mathrm{HCl}(3 \mathrm{M})$ via syringe to the sealed reaction vial. The vials were opened and 20 $\mu \mathrm{L}$ internal standard ( $20 \mathrm{mM}$ 2-phenylethanol in $\mathrm{MeOH}$ ) was added followed by $1 \mathrm{~mL}$ ethyl acetate. This mixture was transferred to a $1.8 \mathrm{~mL}$ Eppendorf tube which was vortexed and centrifuged $(16,000 \times \mathrm{g}, 1 \mathrm{~min})$. The top organic layer was dried over an anhydrous sodium sulfate plug and analyzed by chiral phase GC.

\section{Determination of initial rates}

A slightly modified work-up was implemented for kinetic experiments. The reactions were quenched after the set time by syringing $1 \mathrm{~mL}$ EtOAc to the closed vials and immediately vortexing the mixture. The vials were then opened and $20 \mu \mathrm{L}$ internal standard was added. The mixture was transferred to a $1.8 \mathrm{~mL}$ Eppendorf tube, vortexed and centrifuged $(16,000 \times \mathrm{g}, 1 \mathrm{~min})$. The top organic layer was dried over an anhydrous sodium sulfate plug and analyzed by GC. Both styrene and EDA concentrations were varied in the presence of the enzymes expressed as the heme-domain ( 0.5 or $\left.1.0 \mu \mathrm{M} \mathrm{P} 450_{\mathrm{BM}_{3}-\mathrm{CIS}} \mathrm{heme}\right)$. Reactions were set up in phosphate buffer $(\mathrm{pH}=8.0)$ with $\mathrm{Na}_{2} \mathrm{~S}_{2} \mathrm{O}_{4}$ as the reductant at $25^{\circ} \mathrm{C}$, and were worked-up as described above. Three time points were taken and used to determine the rate of product formation by GC (cyclosil-B $30 \mathrm{~m} \times 0.32 \mathrm{~mm} \times 0.25 \mu \mathrm{m})$ : oven temperature $=$ $100{ }^{\circ} \mathrm{C} 5 \mathrm{~min}, 5{ }^{\circ} \mathrm{C} / \mathrm{min}$ to $200{ }^{\circ} \mathrm{C}, 20^{\circ} \mathrm{C} / \mathrm{min}$ to $250{ }^{\circ} \mathrm{C}, 250{ }^{\circ} \mathrm{C}$ for $5 \mathrm{~min}$. Elution time: ciscyclopropanes (19.20 min and $19.33 \mathrm{~min}$ ), trans-cyclopropanes (20.44 min). Apparent kinetic constants were determined by fitting the data to the standard Michaelis-Menten model. 


\section{Media and cell cultures for in vivo cyclopropanation}

E. coli [BL21(DE3)] cells were grown from glycerol stock overnight $\left(37^{\circ} \mathrm{C}, 250 \mathrm{rpm}\right)$ in 5 ml M9Y medium [ $1 \mathrm{~L}$ of $5 \times$ M9 medium contains $31 \mathrm{~g} \mathrm{Na}_{2} \mathrm{HPO}_{4}, 15 \mathrm{~g} \mathrm{KH}_{2} \mathrm{PO}_{4}, 2.5 \mathrm{~g}$ $\mathrm{NaCl}, 5.0 \mathrm{~g} \mathrm{NH}_{4} \mathrm{Cl}, 0.24 \mathrm{~g} \mathrm{MgSO}_{4}$, and $0.01 \mathrm{~g} \mathrm{CaCl}_{2} .1 \mathrm{~L} \mathrm{M9Y}$ contains $200 \mathrm{~mL} 5 \times \mathrm{M} 9$, $800 \mathrm{~mL}$ deionized water, $15 \mathrm{~g}$ yeast extract, $1 \mathrm{~mL}$ micronutrients, and $0.1 \mathrm{mg} \mathrm{mL}^{-1}$ ampicillin). The pre-culture was used to inoculate $45 \mathrm{~mL}$ of M9Y medium in a $125 \mathrm{~mL}$ Erlenmeyer flask and this culture was incubated at $37^{\circ} \mathrm{C}, 250 \mathrm{rpm}$ for $2 \mathrm{~h}$ and $30 \mathrm{~min}$. At $\mathrm{OD}_{600}=1.2$, the cultures were cooled to $25^{\circ} \mathrm{C}$ and the shaking was reduced to $160 \mathrm{rpm}$ before inducing with IPTG $(0.25 \mathrm{mM})$ and $\delta$-aminolevulinic acid $(0.25 \mathrm{mM})$. Cultures were harvested after $20 \mathrm{~h}$ and resuspended $\left(\mathrm{OD}_{600}=30\right)$ in nitrogen-free $\mathrm{M} 9$ medium $(1 \mathrm{~L}: 31 \mathrm{~g}$ $\mathrm{Na}_{2} \mathrm{HPO}_{4}, 15 \mathrm{~g} \mathrm{KH}_{2} \mathrm{PO}_{4}, 2.5 \mathrm{~g} \mathrm{NaCl}, 0.24 \mathrm{~g} \mathrm{MgSO}_{4}, 0.01 \mathrm{~g} \mathrm{CaCl}_{2}, 1 \mathrm{~mL}$ micronutrients). The micronutrient solution contains $0.15 \mathrm{mM}\left(\mathrm{NH}_{4}\right)_{6} \mathrm{Mo}_{7} \mathrm{O}_{24}, 20.0 \mathrm{mM} \mathrm{H}_{3} \mathrm{BO}_{3}, 1.5 \mathrm{mM}$ $\mathrm{CoCl}_{2}, 0.5 \mathrm{mM} \mathrm{CuSO}_{4}, 4.0 \mathrm{mM} \mathrm{MnCl}_{2}$, and $0.5 \mathrm{mM} \mathrm{ZnSO}_{4}$. Aliquots of the cell suspension were used for determination of the cell dry weight (cdw, $2 \mathrm{~mL}$ ) and P450 (or P411) expression level $(3 \mathrm{~mL})$.

\section{Small-scale whole-cell bioconversions}

Reaction conditions were as follows: 2 eq styrene, 1 eq EDA, 0.2 eq glucose, E. coli wholecells in aqueous nitrogen-free $\mathrm{M} 9$ minimal medium and $5 \% \mathrm{MeOH}$ cosolvent under anaerobic conditions for twelve hours at $25{ }^{\circ} \mathrm{C}$. E. coli cells $\left(\mathrm{OD}_{600}=30,425 \mu \mathrm{L}\right)$ were made anaerobic by bubbling argon through the cell suspension in a crimped $2 \mathrm{~mL}$ vial. A degassed solution of glucose $(50 \mu \mathrm{L}, 20 \mathrm{mM})$ was added to the cells before adding EDA $(12.5 \mu \mathrm{L}$ of a $400 \mathrm{mM}$ solution in $\mathrm{MeOH})$ and olefin $(12.5 \mu \mathrm{L}$ of a $800 \mathrm{mM}$ solution in $\mathrm{MeOH})$. The reactions were stirred at room temperature for the appropriate and were worked up by adding $20 \mu \mathrm{L}$ of the internal standard ( $20 \mathrm{mM}$ 2-phenylethanol) and extracting with $1 \mathrm{~mL}$ ethyl acetate. The organic layer was dried over $\mathrm{Na}_{2} \mathrm{SO}_{4}$ before analyzing the product mixture by chiral phase GC. Yields, diastereomeric ratios, and enantiomeric excess were determined by GC analysis. Yields based on EDA.

\section{Preparative-scale whole-cell bioconversions}

E. coli [BL21(DE3)] cells were grown from glycerol stock overnight $\left(37^{\circ} \mathrm{C}, 250 \mathrm{rpm}\right)$ in 50 $\mathrm{ml}$ M9Y medium. The pre-culture was used to inoculate two $475 \mathrm{~mL}$ of M9Y medium in two $1 \mathrm{~L}$ Erlenmeyer flask (using $25 \mathrm{~mL}$ each) and this culture was incubated at $37^{\circ} \mathrm{C}, 250$ rpm for $2 \mathrm{~h}$ and $30 \mathrm{~min}$. At $\mathrm{OD}_{600}=1.8$, the cultures were cooled to $25^{\circ} \mathrm{C}$ and the shaking was reduced to $150 \mathrm{rpm}$ before inducing with IPTG $(0.25 \mathrm{mM})$ and $\delta$-aminolevulinic acid $(0.25 \mathrm{mM})$. Cultures were harvested after $24 \mathrm{~h}$ and resuspended $\left(\mathrm{OD}_{600}=75\right)$ in nitrogenfree $\mathrm{M} 9$ medium. $E$. coli cells $\left(\mathrm{OD}_{600}=70,53.6 \mathrm{~mL}\right)$ were made anaerobic by bubbling argon through the cell suspension in a $500 \mathrm{~mL}$ sealed round bottom flask. A degassed solution of glucose $(1.4 \mathrm{~mL}, 500 \mathrm{mM})$ was added to the cells before adding EDA (1.36 mL, $85 \%$ EDA in DCM as packaged by Sigma Aldrich) and styrene $(2.5 \mathrm{~mL}$, neat). The reaction was stirred at room temperature under positive argon pressure for $24 \mathrm{~h}$. The crude mixture was poured into three $50 \mathrm{~mL}$ conical tubes and the reaction was quenched by the addition of $\mathrm{HCl}(1 \mathrm{~mL}, 3 \mathrm{M})$ to each tube. The aqueous mixtures were extracted with 1:1 EtOAc: hexanes $(20 \mathrm{~mL}$ each) and centrifuged $(5000 \mathrm{rpm}, 5 \mathrm{~min})$. The organics were collected and 
this extraction sequence was performed two more times. The organics were combined, dried over $\mathrm{Na}_{2} \mathrm{SO}_{4}$ then concentrated. Excess styrene was removed via azeotrope with $\mathrm{H}_{2} \mathrm{O}$ / benzene and $1.85 \mathrm{~g}$ of crude product was isolated. Cis/trans selectivity of the reaction was determined via gas chromatography of this crude mixture. Column chromatography of the crude product with $8 \% \mathrm{Et}_{2} \mathrm{O} /$ hexanes afforded the desired products as a mixture of cis and trans isomers (1.63 g combined, $78 \%$ yield). Based on comparison of crude and purified yields, the crude product was approximately $88 \%$ pure. NMR of the isolated products were identical to those reported in the literature ${ }^{5}$.

\section{Time course of in vivo and in vitro reactions}

Following the procedure for small scale bioconversions, a series of in vivo and in vitro reactions were set up and EDA was added to each sample at time 0 hours. Time points were taken at $0.5,1,1.5,2,3,4,5,6,7$, and 8 hours. Each reported yield reflects an average of two independent reactions that were allowed to stir for the indicated amount of time. The error bars shown reflect the two unaveraged data points. Yields of each reaction were determined by GC.

\section{Thermostability measurements}

Duplicate measurements were taken for all values reported in Supplementary Figure 12. Purified P450 (or P411) solutions ( $4 \mu \mathrm{M}, 200 \mu \mathrm{L})$ were heated in a thermocycler (Eppendorf) over a range of temperatures $\left(40-70{ }^{\circ} \mathrm{C}\right)$ for $10 \mathrm{~min}$ followed by rapid cooling to $4{ }^{\circ} \mathrm{C}$ for $1 \mathrm{~min}$. The precipitate was removed by centrifugation. The concentration of folded P450 (or P411) remaining in the supernatant was measured by CO-difference spectroscopy. The temperature at which half of the protein was denatured $\left(T_{50}\right)$ was

determined by fitting the data to the equation: $f(T)=\frac{100}{1+e^{-a\left(\frac{1}{T}-\frac{1}{T_{50}}\right)}}$.

\section{Supplementary Material}

Refer to Web version on PubMed Central for supplementary material.

\section{Acknowledgments}

This research is supported by the Gordon and Betty Moore Foundation through the Caltech Programmable Molecular Technology Initiative. EMB was supported by a Ruth M. Kirschstein National Institutes of Health (NIH) postdoctoral fellowship Award Number F32GM087102 from the National Institute of General Medical Sciences and a generous startup fund from UNC Chapel Hill. ZJW was supported by NIH 1F32EB015846-01. MEE was supported by NIH Grant RO1-DK019038. We thank Nikki Peck for help with preparative-scale experiments. We thank members of the Redinbo laboratory at UNC Chapel Hill for assistance with X-ray diffraction data collection. MEE thanks Dr. James D. Blakemore for electrodes and helpful discussions.

\section{References}

1. Ajikumar PK, et al. Science. 2010; 330:70-74. [PubMed: 20929806]

2. Westfall PJ, et al. Proc Natl Acad Sci USA. 2012; 109:E111-E118. [PubMed: 22247290]

3. Kataoka M, et al. Appl Microbiol Biotechnol. 2003; 62:437-445. [PubMed: 12838375]

4. Boyce M, Bertozzi CR. Nature Methods. 2011; 8:638-642. [PubMed: 21799498]

5. Coelho PS, Brustad EM, Kannan A, Arnold FH. Science. 2013; 339:307-310. [PubMed: 23258409] 
6. Lebel H, Marcoux JF, Molinaro C, Charette AB. Chem Rev. 2003; 103:977-1050. [PubMed: 12683775]

7. Evans DA, Woerpel KA, Hinman MM, Faul MM. J Am Chem Soc. 1991; 113:726-728.

8. Davies HML, Venkataramani C. Org Lett. 2003; 5:1403-1406. [PubMed: 12713284]

9. Maas G. Chem Soc Rev. 2004; 33:183-190. [PubMed: 15026823]

10. Ost TWB, et al. Biochemistry. 2001; 40:13421-13429. [PubMed: 11695888]

11. Wuttke DS, Gray HB. Curr Opin Struct Biol. 1993; 3:555-563.

12. Reedy CJ, Elvekrog MM, Gibney BR. Nucleic Acids Research. 2008; 36:D307-D313. [PubMed: 17933771]

13. Dawson JH. Science. 1988; 240:433-439. [PubMed: 3358128]

14. Vatsis KP, Peng HM, Coon MJ. J Inorg Biochem. 2002; 91:542-553. [PubMed: 12237221]

15. Wolf JR, Hamaker CG, Djukic JP, Kodadek T, Woo LK. J Am Chem Soc. 1995; 117:9194-9199.

16. Perera R, Sono M, Voegtle HL, Dawson JH. Arch Bioch Bioph. 2011; 507:119-125.

17. Dunford AJ, Girvan HM, Scrutton NS, Munro AW. Biochim Bioph Acta, Proteins and Proteomics. 2009; 1794:1181-1189.

18. Wessjohann LA, Brandt W, Thiemann T. Chem Rev. 2003; 103:1625-1647. [PubMed: 12683792]

19. Penoni A, et al. Eur J Inorg Chem. 2003:1452-1460.

20. Watanabe N, Matsuda H, Kuribayashi H, Hashimoto S-i. Heterocycles. 1996; 42:537-542.

21. Sambrook, J.; Frisch, E.; Maniatis, T. Molecular cloning: a laboratory manual. Vol. 2. Cold Spring Harbor Laboratory Press; New York: 1989.

22. Omura T, Sato R. J Biol Chem. 1964; 239:2370-2378. [PubMed: 14209971]

23. Kabsch W. Acta Crystallogr, Sect D: Biol Crystallogr D. 2010; 66:133-144.

24. Evans P. Acta Crystallogr, Sect D: Biol Crystallogr D. 2006; 62:72-82.

25. Haines DC, Tomchick DR, Machius M, Peterson JA. Biochemistry. 2001; 40:13456-13465.

[PubMed: 11695892]

26. Vagin A, Teplyakov A. Journal of Applied Crystallography. 1997; 30:1022-1025.

27. Bailey S. Acta Crystallogr, Sect D: Biol Crystallogr D. 1994; 50:760-763.

28. Emsley P, Cowtan K. Acta Crystallogr, Sect D: Biol Crystallogr D. 2004; 60:2126-2132.

29. Murshudov GN, Vagin AA, Dodson EJ. Acta Crystallogr, Sect D: Biol Crystallogr D. 1997; 53:240-255.

30. Adams PD, et al. Acta Crystallogr, Sect D: Biol Crystallogr D. 2010; 66:213-221. 


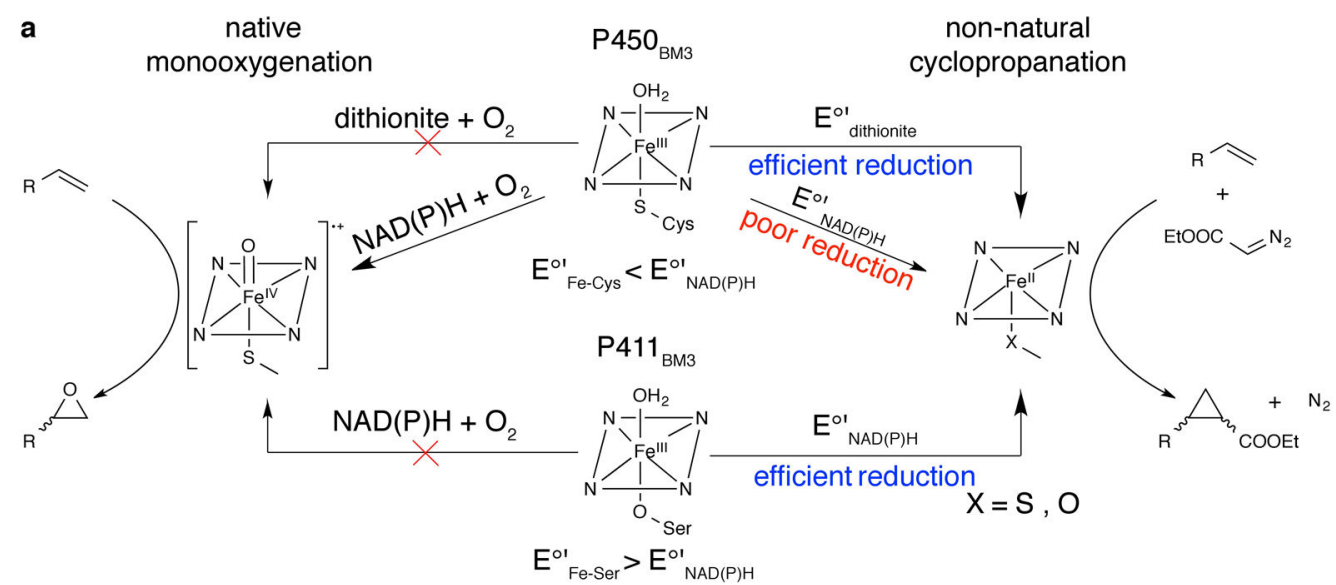

b

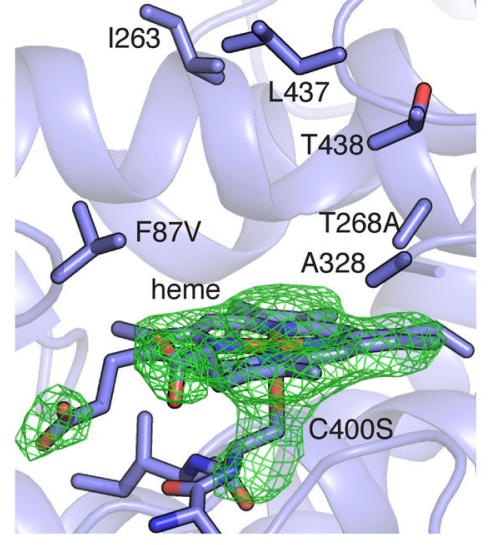

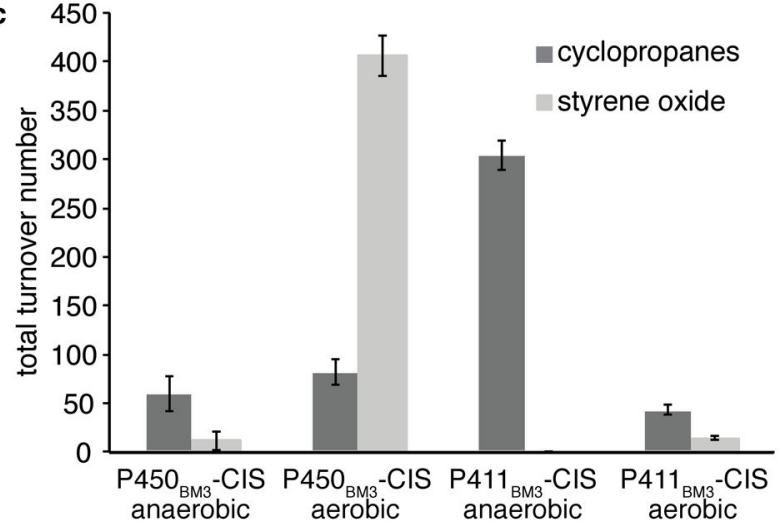

Figure 1.

Contrasting P450- and P411-mediated cyclopropanation. (A) Cytochrome P450s

inefficiently catalyze cyclopropanation using $\mathrm{NAD}(\mathrm{P}) \mathrm{H}$ as a reductant because the $\mathrm{Fe}^{\mathrm{III}} / \mathrm{Fe}^{\mathrm{II}}$ redox potential for the low-spin resting state $\left(E^{\circ} \mathrm{Fe}\right.$-cys $\left.=-430 \mathrm{mV}\right)$ is lower than that of $\mathrm{NAD}(\mathrm{P})^{+} / \mathrm{NAD}(\mathrm{P}) \mathrm{H}\left(\mathrm{E}^{\circ \prime}{ }_{1}=-320 \mathrm{mV}\right.$, right $)$. Mutation of the heme-ligating Cys to Ser allows $\mathrm{NAD}(\mathrm{P}) \mathrm{H}$-driven cyclopropanation while removing native monooxygenation (left).

(B) Close-up of the P411 ${ }_{\mathrm{BM} 3 \text {-heme}}$-CIS active site (PDB: 4H24) superimposed with an $F_{o}$ $F_{c}$ simulated annealing omit map contoured at $3 \sigma$ showing electron density (green mesh) corresponding to the bound heme and C400S mutation. Heme, C400S and additional active site amino acid side chains are shown as sticks. (C) In vitro cyclopropanation vs. epoxidation of styrene catalyzed by $\mathrm{P} 450_{\mathrm{BM}}-\mathrm{CIS}$ and $\mathrm{P} 411_{\mathrm{BM}}-\mathrm{CIS}$ under anaerobic and aerobic conditions. Reaction conditions were as follows: $30 \mathrm{mM}$ styrene, $10 \mathrm{mM}$ EDA, 0.5 mM NADPH, $25 \mathrm{mM}$ glucose, $2 \mathrm{U} \mathrm{ml}^{-1}$ glucose dehydrogenase and $20 \mu \mathrm{M}$ enzyme in aqueous potassium phosphate buffer and $5 \% \mathrm{MeOH}$ cosolvent for six hours at $25^{\circ} \mathrm{C}$. Error bars represent the standard deviation of three independent measurements. 


\section{로을}

롤

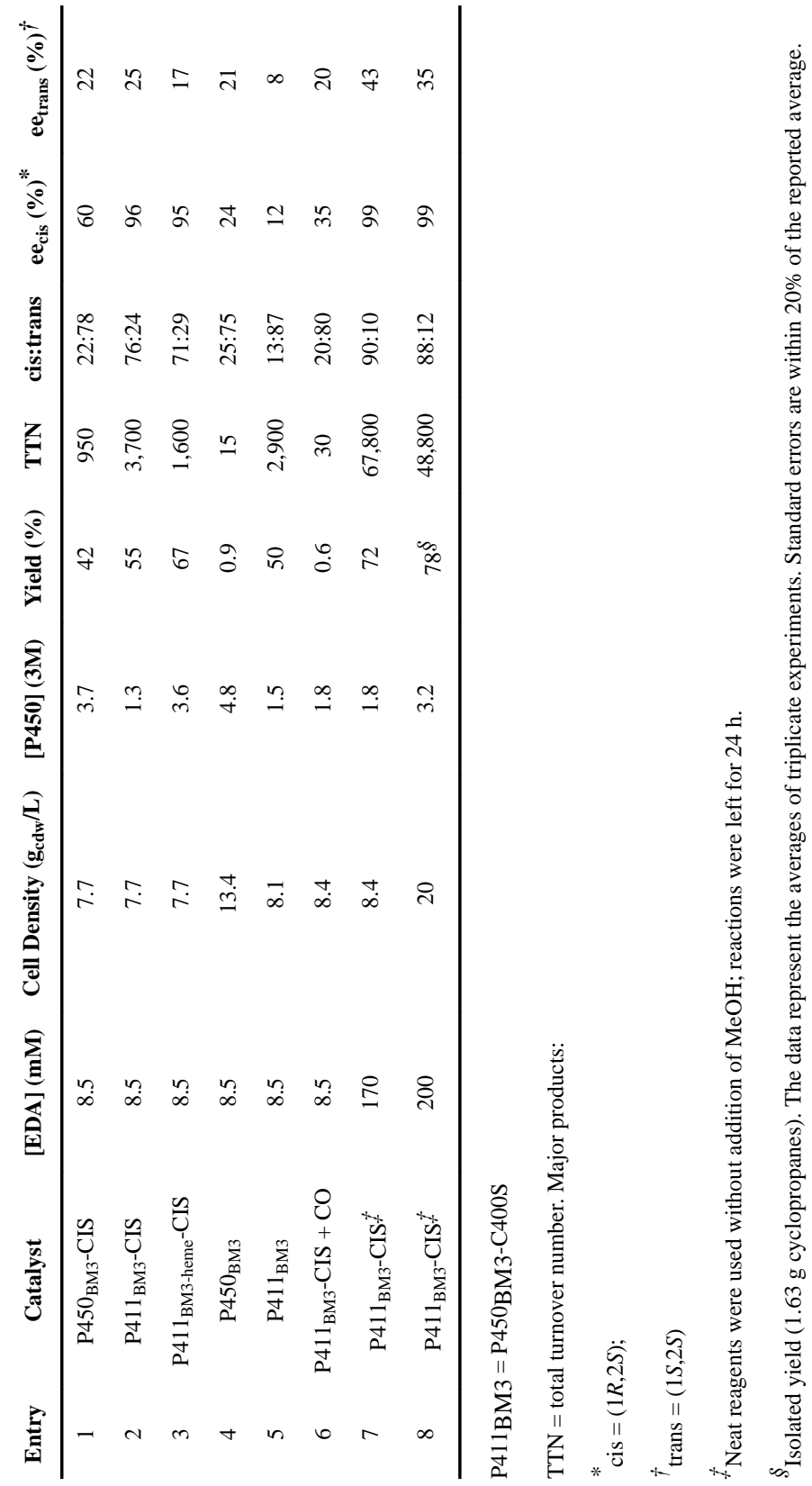

Nat Chem Biol. Author manuscript; available in PMC 2014 February 01. 